\title{
Nocardia pigrifrangens sp. nov., a novel actinomycete isolated from a contaminated agar plate
}

\author{
Liming Wang, ${ }^{1}$ Yamei Zhang, ${ }^{1}$ Ying Huang, ${ }^{1}$ Luis A. Maldonado, ${ }^{2}$ \\ Zhiheng Liu' ${ }^{1}$ and Michael Goodfellow ${ }^{2}$ \\ 'State Key Laboratory of Microbial Resources, Institute of Microbiology, Chinese Academy of \\ Sciences, Beijing 100080, People's Republic of China \\ ${ }^{2}$ School of Biology, University of Newcastle, Newcastle upon Tyne NE1 7RU, UK
}

Correspondence

Zhiheng Liu

zhliu@sun.im.ac.cn

\begin{abstract}
A polyphasic study was undertaken to establish the taxonomic position of an actinomycete strain isolated from a contaminated agar plate. The strain, designated $7031^{\top}$, had morphological and chemotaxonomic properties typical of the genus Nocardia. An almost-complete $16 \mathrm{~S}$ rRNA gene sequence determined for the strain was aligned with available sequences for nocardiae, and phylogenetic trees were inferred using three tree-generating algorithms. Strain $7031^{\top}$ clustered with the type strains of Nocardia carnea and Nocardia flavorosea, showing low $16 \mathrm{~S}$ rRNA gene sequence similarities to these species ( $97 \cdot 2$ and $97 \cdot 5 \%$, respectively). The strain was also distinguished from the closest species by a range of phenotypic properties. It is proposed that the strain be recognized as a novel species of Nocardia, Nocardia pigrifrangens sp. nov., the type strain of which is $7031^{\top}\left(=\mathrm{AS} 4.1808^{\top}=\mathrm{JCM} 11884^{\top}\right)$.
\end{abstract}

The genus Nocardia is well defined as a result of the application of complementary genotypic and phenotypic methods (Goodfellow et al., 1999; Yassin et al., 2003). The improved classification provides an invaluable framework for the delineation of additional species. The genus encompasses 36 recognized species at the time of writing, 20 of which have been described in the last 5 years. Members of most of the latter have been isolated either from clinical material (Yassin et al., 2000a, b, 2001a, b, 2003; Gürtler et al., 2001; Hamid et al., 2001; Kageyama et al., 2004a, b) or from environmental samples, notably soil (Maldonado et al., 2000; Kinoshita et al., 2001; Wang et al., 2001; Kämpfer et al., 2004; Saintpierre-Bonaccio et al., 2004; Albuquerque de Barros et al., 2003). Despite this rapid expansion in the number of described species, it is evident that additional nocardial diversity has still to be formally described (Orchard \& Goodfellow, 1980; Wang et al., 1999; Maldonado et al., 2000; Roth et al., 2003).

In the course of ongoing studies on unusual actinomycetes, a strain isolated from a contaminated Bennett's agar plate (Zhang et al., 2003) was considered to belong to the genus

Published online ahead of print on 13 April 2004 as DOI 10.1099/ ijs.0.03035-0.

The GenBank/EBML/DDBJ accession number for the 16S rRNA gene sequence of strain $7031^{\top}$ is AF219974.

$16 \mathrm{~S}$ rRNA signatures of representative Nocardia species are available as supplementary data in IJSEM Online.
Nocardia based on morphological criteria. The aim of the present study was to determine the taxonomic position of this isolate using a polyphasic taxonomic approach.

The colonial properties of strain $7031^{\mathrm{T}}$ were recorded from a modified Bennett's agar plate (Zhang et al., 2003) that had been incubated for 7 days at $28^{\circ} \mathrm{C}$. It was also examined for a broad range of phenotypic properties using standard procedures (Goodfellow, 1971). The biochemical and degradative tests were carried out after Gordon \& Mihm (1957) and the carbon utilization tests according to Yassin et al. (1995). Biomass for most of the chemotaxonomic tests was prepared in Sauton's broth as described by Zhang et al. (2003). Established TLC procedures were used to determine the diagnostic isomers of diaminopimelic acid (Lechevalier \& Lechevalier, 1980) and menaquinone (Collins et al., 1987), polar lipid (Yassin et al., 1993) and whole-organism sugar patterns (Lechevalier \& Lechevalier, 1980). Mycolic acids were detected using the acid methanolysis procedure (Minnikin et al., 1975). Biomass for the quantitative fatty acid analysis was prepared from trypticase soy broth agar plates after Zhang et al. (2003). The non-hydroxylated fatty acids were extracted, purified, methylated, identified and quantified by GC using the standard MIDI (Microbial Identification) system (Sasser, 1990; Kämpfer \& Kroppenstedt, 1996).

Chromosomal DNA from strain $7031^{\mathrm{T}}$ was isolated and purified following the procedure described by Yassin et al. (2000a). The $G+C$ content of the DNA was determined 
using the thermal denaturation method (Marmur \& Doty, 1962) with Escherichia coli AS 1.365 as control. Genomic DNA extraction, PCR-mediated amplification of the $16 \mathrm{~S}$ rRNA gene and purification of the PCR products were carried out following the procedures of Rainey et al. (1996). Purified PCR products were sequenced directly using a Taq Dye Deoxy Terminator cycle sequencing kit (Applied Biosystems) and universal primers as described by Lu et al. (2001). Sequence gel electrophoresis was carried out and nucleotide sequences were obtained automatically using an Applied Biosystems DNA sequencer (model 377) and software provided by the manufacturer.

An almost-complete 16S rRNA gene sequence of strain $7031^{\mathrm{T}}$ (1419 nt) was aligned manually with corresponding nucleotide sequences of representatives of recognized Nocardia species, available from public databases, using the PHYDIT program (Chun, 1995). Evolutionary trees were inferred using the least-squares (Fitch \& Margoliash, 1967), maximum-parsimony (Kluge \& Farris, 1969) and neighbour-joining (Saitou \& Nei, 1987) tree-making algorithms. The robustness of the resultant trees was evaluated by a bootstrap analysis (Felsenstein, 1985) of the neighbourjoining dataset using the SEQBOOT and CONSENSE options from the PHYLIP package.

Strain $7031^{\mathrm{T}}$ exhibited a range of phenotypic properties typical of members of the genus Nocardia (Goodfellow et al., 1999). The organism is an aerobic, Gram-positive, slightly acid-alcohol-fast actinomycete, which forms an extensively branched orange substrate mycelium that fragments into rod-shaped, non-motile elements and supports abundant white aerial hyphae on modified Bennett's agar. Wholeorganism hydrolysates of the organism are rich in meso-diaminopimelic acid, arabinose and galactose (wall chemotype IV sensu Lechevalier \& Lechevalier, 1970) and diphosphatidylglycerol, phosphatidylethanolamine, phosphatidylinositol and phosphatidylinositolmannosides (phospholipid lipid type II sensu Lechevalier et al., 1977). The isolate contains hexahydrogenated menaquinones with eight isoprene units, in which the end two are cyclized; this menaquinone is restricted to members of the genera Nocardia and Skermania (Chun et al., 1997; Goodfellow et al., 1999). The fatty acid profile mainly consists of straight-chain saturated, unsaturated and 10-methyl branched components. The $\mathrm{G}+\mathrm{C}$ content of the DNA is $68 \cdot 7 \mathrm{~mol} \%$.

The unrooted phylogenetic tree (Fig. 1) shows that strain $7031^{\mathrm{T}}$ and the type strains of Nocardia carnea and Nocardia flavorosea form a clade that is loosely associated with a taxon that encompasses the type strains of Nocardia brevicatena and Nocardia paucivorans. The taxonomic integrity of the two clades is supported by analyses based on all three treemaking algorithms and by a high bootstrap value with the neighbour-joining method. It is known that the type strains of N. carnea and N. flavorosea share a high 16S rRNA gene sequence similarity $(99 \cdot 2 \%$ or $12 \mathrm{nt}$ differences out of 1472 positions) but belong to genomic species with a mean

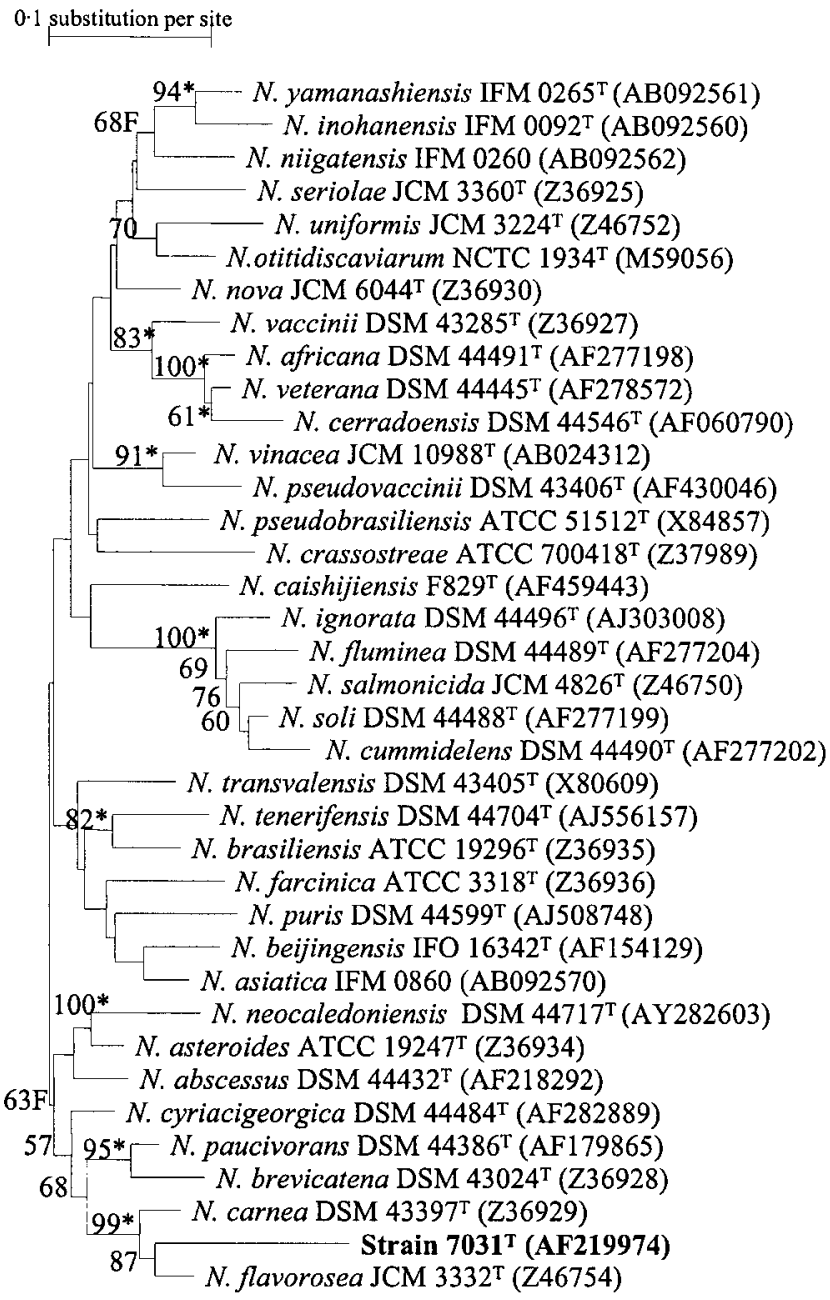

Fig. 1. Unrooted neighbour-joining tree (Saitou \& Nei, 1987), based on almost-complete 16S rRNA gene sequences, showing the position of strain $7031^{\top}$ within the genus Nocardia. Asterisks indicate the branches of the tree that were also recovered using both the least-squares (Fitch \& Margoliash, 1967) and maximum-parsimony (Kluge \& Farris, 1969) treemaking algorithms. Numbers at the nodes indicate levels of bootstrap support based on a neighbour-joining analysis of 1000 resampled datasets; only values above $50 \%$ are given.

DNA-DNA relatedness value of $5 \%$ (Chun et al., 1998). It is, therefore, evident that the low $16 \mathrm{~S}$ rRNA gene sequence values found between strain $7031^{\mathrm{T}}$ and the type strains of N. carnea and N. flavorosea, namely 97.2 and $97.5 \%$, respectively, indicate that the test strain forms a distinct centre of taxonomic variation in the $N$. carnea clade. It is clear from Table 1 that strain $7031^{\mathrm{T}}$ can be distinguished readily from the type strains of N. carnea and N. flavorosea using a combination of phenotypic properties. These organisms can also be distinguished by a number of $16 \mathrm{~S}$ rRNA signatures (results are available as supplementary data in IJSEM Online). 
Table 1. Phenotypic characteristics that distinguish strain $7031^{\top}$ from representatives of phylogenetically close Nocardia species

Strains: $1,7031^{\mathrm{T}} ; 2$, N. carnea DSM $43397^{\mathrm{T}} ; 3$, N. flavorosea JCM $3332^{\mathrm{T}}$. Data were taken from this and previous studies (Orchard \& Goodfellow, 1980; Chun et al., 1998; Zhang et al., 2003). +, Positive; -, negative.

\begin{tabular}{|c|c|c|c|}
\hline Character & 1 & 2 & 3 \\
\hline Aesculin hydrolysis & - & + & - \\
\hline Arbutin hydrolysis & + & - & + \\
\hline Nitrate reduction & + & + & - \\
\hline Urea hydrolysis & + & - & - \\
\hline \multicolumn{4}{|l|}{ Decomposition of: } \\
\hline Uric acid & + & - & - \\
\hline \multicolumn{4}{|c|}{ Growth on sole carbon sources $(\%, w / v)$ : } \\
\hline$(+)$-D-Glucose $(1 \cdot 0)$ & + & + & - \\
\hline$(+)$-D-Mannitol $(1 \cdot 0)$ & - & + & + \\
\hline$(+)$-D-Sorbitol $(1 \cdot 0)$ & - & + & + \\
\hline Sodium acetate $(0 \cdot 1)$ & + & - & + \\
\hline Sodium benzoate $(0 \cdot 1)$ & + & - & - \\
\hline Sodium citrate $(0 \cdot 1)$ & - & - & + \\
\hline Growth at $45^{\circ} \mathrm{C}$ & - & - & + \\
\hline
\end{tabular}

The combined genotypic and phenotypic data indicate that strain $7031^{\mathrm{T}}$ merits recognition as a novel species in the genus Nocardia; the name proposed for this new taxon is Nocardia pigrifrangens sp. nov.

\section{Description of Nocardia pigrifrangens sp. nov.}

Nocardia pigrifrangens (L. adj. piger slow; L. part. adj. frangens from L. v. frango to break up small; N.L. part. adj. pigrifrangens slow to break up; frango referring to the fact that the substrate mycelium remains stable for up to 14 days before undergoing fragmentation).

Aerobic, Gram-positive, catalase-positive, slightly acidalcohol-fast, non-motile actinomycete that produces an orange substrate mycelium that fragments in situ into irregular rod-shaped elements and which bears sparse white to pinkish aerial hyphae on modified Bennett's, modified Sauton's and oatmeal agars. Colonies are convex with filamentous margins. Does not degrade adenine, casein, elastin, hypoxanthine, tyrosine or xanthine. Growth occurs between 18 and $35^{\circ} \mathrm{C}$. (-)-D-Arabinose, (+)-D-cellobiose, dulcitol, meso-erythritol, ethanol, (-)-D-fructose, glycerol, glycogen, inulin, $(+)$-D-mannose, $(-)$-D-ribose, $(+)$-Dsalicin, $(+)$-D-sucrose, $(+)$-D-trehalose, $(+)$-D-xylose (all at $1 \%, \mathrm{w} / \mathrm{v})$, gluconate, $p$-hydroxybenzoic acid, sodium $\mathrm{H}$-malate, pyruvate and succinate (all at $0 \cdot 1 \%, \mathrm{w} / \mathrm{v}$ ) are used as sole carbon sources for energy and growth, but not adonitol, (+)-D-galactose, (+)-D-lactose, (+)-Dmaltose, $(+)$-D-melezitose, $(+)$-D-melibiose, methyl $\alpha$-Dglucopyranoside, $(+)$-D-raffinose, $\alpha$-L-rhamnose, xylitol (all at $1 \%, \mathrm{w} / \mathrm{v}$ ), iso-amyl alcohol, iso-butanol, n-propanol (all at $1 \%, \mathrm{v} / \mathrm{v}$ ), butyrate or $m$-hydroxybenzoic acid.
L-Alanine, L-aspartate, L-glutamate, monoethanolamine, L-proline, uric acid and L-valine are used as sole carbon and nitrogen sources, but not acetamide, gelatin, L-leucine, L-phenylalanine or urea (all at $0 \cdot 1 \%, \mathrm{w} / \mathrm{v}$ ). Additional phenotypic properties are shown in Table 1 . The major cellular fatty acids are $\mathrm{C}_{16: 1} \omega 7 c(8.9 \%), \mathrm{C}_{16: 0}(18 \cdot 0 \%)$, $\mathrm{C}_{18: 1} \omega 9 c(17 \cdot 6 \%), \mathrm{C}_{18: 0}(30 \cdot 5 \%) 10$-methyl-C $\mathrm{C}_{18: 0}(21 \%)$ and $\mathrm{C}_{21: 1} \omega 9 c(4 \cdot 1 \%)$. The $\mathrm{G}+\mathrm{C}$ content of the DNA is $68 \cdot 7 \mathrm{~mol} \%$.

The type strain, $7031^{\mathrm{T}}\left(=\right.$ AS $\left.4.1808^{\mathrm{T}}=\mathrm{JCM} 11884^{\mathrm{T}}\right)$, was isolated from a contaminated agar plate of a clinically significant strain in Shanghai, People's Republic of China.

\section{Acknowledgements}

This work was supported through The Royal Society-Chinese Academy of Sciences Exchange Scheme (grant no. Q814), by the National Science Foundation of China (grant no. 39570002) and by the Key Laboratory for Microbial Resources of the Educational Board of China. The authors are also grateful to Dr T. Kudo (JCM) for providing some of the Nocardia strains and to Dr J. Euzéby for help with the construction of the species name.

\section{References}

Albuquerque de Barros, E. V. S., Manfio, G. P., Ribeiro Maitan, V., Mendes Bataus, L. A., Kim, S. B., Maldonado, L. A. \& Goodfellow, M. (2003). Nocardia cerradoensis sp. nov., a novel isolate from Cerrado soil in Brazil. Int J Syst Evol Microbiol 53, 29-33.

Chun, J. (1995). Computer-assisted classification and identification of Actinomycetes. PhD thesis, University of Newcastle, UK.

Chun, J., Blackall, L. L., Kang, S. O., Hah, Y. C. \& Goodfellow, M. (1997). A proposal to reclassify Nocardia pinensis Blackall et al. as Skermania piniformis gen. nov., comb. nov. Int J Syst Bacteriol 47, 127-131.

Chun, J., Seong, C.-N., Bae, K.-S., Lee, K.-J., Kang, S. O., Goodfellow, M. \& Hah, Y.-C. (1998). Nocardia flavorosea sp. nov. Int J Syst Bacteriol 48, 901-905.

Collins, M. D., Howarth, O. W., Grund, E. \& Kroppenstedt, R. M. (1987). Isolation and structural determination of new members of the vitamin $\mathrm{K}_{2}$ series in Nocardia brasiliensis. FEMS Microbiol Lett 41, 35-39.

Felsenstein, J. (1985). Confidence limits on phylogenies: an approach using the bootstrap. Evolution 39, 783-791.

Fitch, W. M. \& Margoliash, E. (1967). Construction of phylogenetic trees. Science 155, 279-284.

Goodfellow, M. (1971). Numerical taxonomy of some nocardioform bacteria. J Gen Microbiol 69, 33-80.

Goodfellow, M., Isik, K. \& Yates, E. (1999). Actinomycete systematics: an unfinished synthesis. Nova Acta Leopold 312, 47-82.

Gordon, R. E. \& Mihm, J. M. (1957). A comparative study of some strains received as nocardiae. J Bacteriol 73, 15-27.

Gürtler, V., Smith, R., Mayall, B. C., Potter-Reinemann, G., Stackebrandt, E. \& Kroppenstedt, R. M. (2001). Nocardia veterana sp. nov., isolated from human bronchial lavage. Int J Syst Evol Microbiol 51, 933-936.

Hamid, M. E., Maldonado, L., Eldin, G. S. S., Mohamed, M. F., Saeed, N. S. \& Goodfellow, M. (2001). Nocardia africana sp. nov., a new pathogen isolated from patients with pulmonary infections. J Clin Microbiol 39, 625-630. 
Kageyama, A., Poonwan, N., Yazawa, K., Mikami, Y. \& Nishimura, K. (2004a). Nocardia asiatica sp. nov., isolated from patients with nocardiosis in Japan and clinical specimens from Thailand. Int J Syst Evol Microbiol 54, 125-130.

Kageyama, A., Yazawa, K., Nishimura, K. \& Mikami, Y. (2004b). Nocardia inohanensis sp. nov., Nocardia yamanashiensis sp. nov. and Nocardia niigatensis sp. nov., isolated from clinical specimens. Int J Syst Evol Microbiol 54, 563-569.

Kämpfer, P. \& Kroppenstedt, R. M. (1996). Numerical analysis of fatty acid patterns of coryneform bacteria and related taxa. Can J Microbiol 42, 989-1005.

Kämpfer, P., Buczolits, S., Jäckel, I., Grün-Wollny, I. \& Busse, H.-J. (2003). Nocardia tenerifensis sp. nov. Int J Syst Evol Microbiol 54, 381-383.

Kinoshita, N., Homma, Y., Igarashi, M., Ikeno, S., Hori, M. \& Hamada, M. (2001). Nocardia vinacea sp. nov. Actinomycetologica 15, $1-5$.

Kluge, A. G. \& Farris, F. S. (1969). Quantitative phyletics and the evolution of anurans. Syst Zool 18, 1-32.

Lechevalier, M. P. \& Lechevalier, H. (1970). Chemical composition as a criterion in the classification of aerobic actinomycetes. Int J Syst Bacteriol 20, 435-443.

Lechevalier, M. P. \& Lechevalier, H. A. (1980). The chemotaxonomy of actinomycetes. In Actinomycete Taxonomy, Special Publication 6, pp. 227-291. Edited by A. Dietz. Arlington, VA: Society for Industrial Microbiology.

Lechevalier, M. P., De Biévre, C. \& Lechevalier, H. A. (1977). Chemotaxonomy of aerobic actinomycetes: phospholipid composition. Biochem Syst Ecol 5, 249-260.

Lu, Z., Liu, Z., Wang, L., Zhang, Y., Qi, W. \& Goodfellow, M. (2001). Saccharopolyspora flava sp. nov. and Saccharopolyspora thermophila sp. nov., novel actinomycetes from soil. Int J Syst Evol Microbiol 51, 319-325.

Maldonado, L., Hookey, J. V., Ward, A. C. \& Goodfellow, M. (2000). The Nocardia salmonicida clade, including descriptions of Nocardia cummidelens sp. nov., Nocardia fluminea sp. nov. and Nocardia soli sp. nov. Antonie van Leeuwenhoek 78, 367-377.

Marmur, J. \& Doty, P. (1962). Determination of base composition of deoxyribonucleic acid from its denaturation temperature. J Mol Biol 4, 109-118.

Minnikin, D. E., Alshamaony, L. \& Goodfellow, M. (1975). Differentiation of Mycobacterium, Nocardia, and related taxa by thin-layer chromatographic analysis of whole-organism methanolysates. J Gen Microbiol 88, 200-204.

Orchard, V. A. \& Goodfellow, M. (1980). Numerical classification of some named strains of Nocardia asteroides and related isolates from soil. J Gen Microbiol 118, 295-312.
Rainey, F. A., Ward-Rainey, N., Kroppenstedt, R. M. \& Stackebrandt, E. (1996). The genus Nocardiopsis represents a phylogenetically coherent taxon and a distinct actinomycete lineage: proposal of Nocardiopsaceae fam. nov. Int J Syst Bacteriol 46, 1088-1092.

Roth, A., Andrees, S., Kroppenstedt, R. M., Harmsen, D. \& Mauch, H. (2003). Phylogeny of the genus Nocardia based on reassessed $16 \mathrm{~S}$ rRNA gene sequences reveals underspeciation and division of strains classified as Nocardia asteroides into three established species and two unnamed taxons. J Clin Microbiol 41, 851-856.

Saintpierre-Bonaccio, D., Maldonado, L. A., Amir, H., Pineau, R. \& Goodfellow, M. (2004). Nocardia neocaledoniensis sp. nov., a novel actinomycete isolated from a New-Caledonian brown hypermagnesian ultramafic soil. Int J Syst Evol Microbiol 54, 599-603.

Saitou, N. \& Nei, M. (1987). The neighbor-joining method: a new method for reconstructing phylogenetic trees. Mol Biol Evol 4, 406-425.

Sasser, M. (1990). Identification of Bacteria by Gas Chromatography of Cellular Fatty Acids. Technical Note 101. Newark, DE: MIDI.

Wang, Y., Zhang, Z., Ruan, J., Wang, Y. \& Ali, S. (1999). Investigations of actinomycete diversity in the tropical rainforests of Singapore. J Ind Microbiol Biotechnol 23, 178-187.

Wang, L., Zhang, Y., Lu, Z., Shi, Y., Liu, Z., Maldonado, L. \& Goodfellow, M. (2001). Nocardia beijingensis sp. nov., a novel isolate from soil. Int J Syst Evol Microbiol 51, 1783-1788.

Yassin, A. F., Haggenei, B., Budzikiewicz, H. \& Schaal, K. P. (1993). Fatty acid and polar lipid composition of the genus Amycolatopsis: application of fast atom bombardment-mass spectrometry to structure analysis of underivatized phospholipids. Int J Syst Bacteriol 43, 414-420.

Yassin, A. F., Rainey, F. A., Brzezinka, H., Burghardt, J., Lee, H. J. \& Schaal, K. P. (1995). Tsukamurella inchonensis sp. nov. Int J Syst Bacteriol 45, 522-527.

Yassin, A. F., Rainey, F. A., Burghardt, J., Brzezinka, H., Mauch, M. \& Schaal, K. P. (2000a). Nocardia paucivorans sp. nov. Int J Syst Evol Microbiol 50, 803-809.

Yassin, A. F., Rainey, F. A., Mendrock, U., Brzezinka, H. \& Schaal, K. P. (2000b). Nocardia abscessus sp. nov. Int J Syst Evol Microbiol 50, 1487-1493.

Yassin, A. F., Rainey, F. A. \& Steiner, U. (2001a). Nocardia cyriacigeorgici sp. nov. Int J Syst Evol Microbiol 51, 1419-1423.

Yassin, A. F., Rainey, F. A. \& Steiner, U. (2001b). Nocardia ignorata sp. nov. Int J Syst Evol Microbiol 51, 2127-2131.

Yassin, A. F., Sträubler, B., Schumann, P. \& Schaal, K. P. (2003). Nocardia puris sp. nov. Int J Syst Evol Microbiol 53, 1595-1599.

Zhang, J., Liu, Z. \& Goodfellow, M. (2003). Nocardia caishijiensis sp. nov., a novel soil actinomycete. Int J Syst Evol Microbiol 53, 999-1004. 